\title{
Does smoking affect your skin?
}

\author{
Katarzyna Lipa ${ }^{1}$, Natalia Zając ${ }^{1}$, Witold Owczarek², Piotr Ciechanowicz', Elżbieta Szymańska ${ }^{1}$, Irena Walecka ${ }^{1}$
}

${ }^{1}$ Department of Dermatology, Centre of Postgraduate Medical Education, Central Clinical Hospital of the Ministry of the Interior, Warsaw, Poland

2Department of Dermatology, Military Institute of Medicine, Warsaw, Poland

Adv Dermatol Allergol 2021; XXXVIII (3): 371-376 DOI: https://doi.org/10.5114/ada.2021.103000

\begin{abstract}
Smoking has a negative influence on human beings. Carcinogens detected in smoke can increase the risk of developing chronic disorders, cancer and premature death. Nicotine can also affect dermatological diseases such as psoriasis, hidradenitis suppurativa, chronic dermatoses, alopecia, lupus erythematosus, polymorphous light eruption, skin cancer and tobacco-associated oral lesions. Advanced education at a doctor's surgery in various medical occupations can change the bad habits and protect people from the consequences.
\end{abstract}

Key words: smoking, nicotine, tobacco, skin.

\section{Introduction}

The World Health Organization (WHO) reports that nearly half of addicted people are killed by smoking. More than eight million people are killed due to smoking each year. According to WHO data, in 2025 there will be still around 1.1 billion smokers worldwide. A relatively easy addiction to smoking is due to a chemical characteristic of the alkaloid contained in tobacco called nicotine that is easily absorbed into the respiratory tract, skin and intestinal mucosa. It is metabolised through the liver to active metabolites [1, 2]. Nicotine can react with different subtypes of nicotinic acetylcholine receptors which are located not only in the nervous system, adrenal medulla, but also in skin keratinocytes and inflammatory cells (monocytes and dendritic cells). Nicotine passes into the nicotinic acetylcholine receptors and transitionally activates ganglionic transmission which is followed by a lasting depression (biphasic effect), initially causes release of catecholamines from the adrenal medulla and postganglionic sympathetic neurons. Nicotine can have an influence on the skin, increase keratinocyte adhesion and upward migration in the epidermis. After all, it provokes the immunomodulatory system [3]. We observe the dysfunction of some structures due to extended exposure to benzo(a)pyrene such as decreased mass of lymphoid tissue and incorrect work of the neutrophils [4]. After meta-analysis resolution, we differentiate the relationship between gender and the result of smoking. Moreover, smoking women have increased morbidity and mortality compared to smoking men [5]. Nicotine is a very insidious factor, which can pass into the human body through smoke inhalation, ingestion, intranasal spray, transdermal patch, topical cream, or enema. Furthermore, nicotine can also be located naturally in small quantities in some vegetables such as tomatoes, potatoes, and aubergines. This chemical bound is absorbed through the oral cavity, lung, bladder, gastrointestinal tract and skin. There was a detailed study of gene expression showing that nicotine contains 14 miscellaneous genes involved in the xenobiotic metabolism, oxidative stress and stress response [6]. Activation of a few pathways releasing cytokines stimulate $T$ lymphocytes leading to the initiation of a chronic inflammatory process [7]. Apart from genetic factors, exposure to nicotine in untimely infancy is related to diseases such as psoriasis [8]. Nicotine is not a carcinogen, but it is a highly addictive chemical compound. Despite this, it is a medically approved medicine as a replacement therapy, used to help with quitting smoking or stopping chewing tobacco [9].

\section{Eye detected characteristics of smokers}

Smokers can be easily identified by their bad habit. The characteristics are yellow discolouration of lightcoloured moustaches, problems with normal nail growth and discoloured fingernails - Harlequin or quitter's nails. About one third of tobacco users have oral pigmentation that is visible to the naked eye [10]. The special case is that gingival pigmentation can be also visible in children of parents with sublingual nicotine use or exposed

Address for correspondence: Prof. Witold Owczarek MD, PhD, Department of Dermatology, Military Institute of Medicine, 128 Szaserów St, 04-141 Warsaw, Poland, phone: 261817 666, +48 2281080 89, e-mail: witold.owczarek@dermedicus.pl Received: 1.12 .2020 , accepted: 21.12 .2020$. 
to passive smoking. Parts of the oral cavity such as the tongue or the palate might also be affected. Most common problems are black hairy tongue, hyperplasia of the papillae with black pigmentation on the dorsal surface of the tongue, leukokeratosis, nicotine glossy and inflammation of salivary glands [10].

\section{Smoking effects}

\section{Premature ageing}

Smoking is an undeniable risk factor for wrinkling and premature skin ageing. This negative influence on the skin was discovered more than 150 years ago. Pathogenesis of smoke-induced ageing is multifactorial. Smoking can affect reticular dermis by increasing the number of elastic fibres resulting in changes similar to solar elastosis [11]. Smoking can lead to the activation of metalloproteinase which can cause degradation of collagen, elastic fibres and proteoglycans [12]. Smoking can also reduce the level of active form of the transforming growth factor $\beta 1$ (TGF- $\beta 1$ ) and down-regulate their receptors causing dysfunctions of tissue remodelling and repairing. An in vivo study showed that mice treated with intracutaneous or topical tobacco smoke can have a decreased level of type I collagen [13, 14]. "Smoker's face" presents some characteristic features such as prominent wrinkles, prominence of underlying bony contours and grey-coloured, atrophic complexion of the skin [10]. Ageing is correlated with pack-years of smoking and number of cigarettes smoked per day [15]. Studies confirmed the association especially with more than 40 packs smoked per year $[16,17]$.

\section{Wound healing}

Smoking is a risk factor for delayed wound healing and other complications. It can affect cutaneous blood flow causing microcirculation and tissue oxygenation disorders [10]. Moreover, smoking can decrease activity of fibroblasts, reducing their migration into the wound [18-20]. Smoking can lead to wound infections [21-23], dehiscence of the wound [24, 25], graft and flap necrosis $[26,27]$. Surgeons suggest patients to quit smoking before operations. Some surgeons hesitate to perform operations on smokers if they refuse to quit [28].

\section{Psoriasis}

Smoking is a factor that can aggravate the clinical symptoms of psoriasis [29]. Smokers compared to nonsmokers have an increased possibility to develop psoriasis [30]. Children who are in very early years exposed to the cigarette smoke are in a group with a higher risk of psoriasis development [8]. There are a few pathways to induce the psoriasis such as genetic, inflammatory or oxidative mechanisms [31]. Chronic inflammation which is a trigger to psoriasis is incited by released cytokines, which activates T lymphocytes [32]. Both smoking and obesity can cause an elevated serum concentration of tumour necrosis factor $\alpha$ (TNF- $\alpha)$ [33]. A protracted inflammatory process increases the risk of cardiovascular incidents [34]. A number of pack years correlates to the level of TNF- $\alpha$ [35]. Also, another inflammatory indicator such as C-reactive protein is increased at a higher age and in a group of smokers [36]. According to the research, smoking can decrease the response of medical treatment. For example, better response to treatment with etanercept, fumaric acid, retinoids (after 3, 6, 12 months of treatment), cyclosporine A (after 6, 12 months of treatment) is noticed in groups of non-smokers compared to smokers [37]. A prospective pharmacovigilance study (BADBIR) revealed that even one episode of smoking can be connected with reducing treatment response in a group of patients on biological therapy $(n=3,079$ at 6 months and $n=3,110$ at 12 months).

\section{Chronic dermatoses and smoking}

Smoking can be a risk factor for developing allergic contact dermatitis. There are a lot of different allergens in the filter, paper and tobacco. The most common are menthol, formaldehyde, cocoa, liquorice, and colophony [38]. Smoking can be a factor inducing a positive patch reaction to nickel [39]. Smoking can increase the serum total IgE level [40]. Cigarette use is also a well-known risk factor for hand eczema [41].

\section{Hidradenitis suppurativa}

Many studies revealed a correlation between smoking and hidradenitis suppurativa. Almost $98 \%$ of patients with this disease are addicted to nicotine [42-45]. Moreover, smokers have been proved to have more severe symptoms [46]. Nicotine is a factor that can cause increased activity of sweat glands. Furthermore, it can affect chemotaxis of granulocytes and macrophages [43, 44]. In vitro studies showed that nicotine can promote hyperplasia of epidermis and follicular plugging [47, 48].

\section{Acne}

Correlation between acne and smoking cigarettes is subject of many studies. However, results of those studies are conflicting. There are some studies that showed a positive effect $[49,50]$ and those which showed a negative impact of smoking [51].

\section{Alopecia}

Smoking is a well-known risk factor for androgenic alopecia among men. Studies showed that smoking over 20 cigarettes per day can be associated with developing moderate to severe androgenic alopecia [52]. Nicotine can cause microcirculation dysfunctions among hair papilla. Cigarette smoke is a source of substances which can cause DNA mutation. Studies revealed that smok- 
ing can affect the balance between proteases and antiproteases. Moreover, it can increase pro-inflammatory cytokine concentration in anagen hair which can lead to follicular microinflammation and fibrosis [53]. Nicotine can decrease the estrogenic level due to stimulation of estradiol hydroxylation and inhibition of aromatase [54].

\section{Lupus erythematosus}

It has been documented that smoking and lupus erythematosus are connected. Some studies proved that smokers have an increased risk of developing SLE $[55,56]$. On the other hand, some of the observational studies demonstrated no association [57, 58]. Smoking can also increase activity of the disease. In addition, it can be a risk factor for developing cutaneous lupus erythematosus including subacute cutaneous lupus erythematous and discoid lupus erythematosus [59-61]. Smokers with discoid lupus erythematosus (DLE) can have a more severe onset of the disease. Nicotine can also interfere with antimalarial therapy by decreasing treatment efficiency [62-64].

\section{Polymorphous light eruption}

A retrospective case-control study including 74 patients with PMLE and 102 controls was conducted. It has shown that people who smoke more than 15 cigarettes daily have an increased risk of developing polymorphous light eruptions [65].

\section{Skin cancer}

The most detailed list of harmful and potentially harmful constituents in tobacco smoke includes about 80 carcinogens (FDA HPHC List) [66]. Despite the fact that carcinogens are present in tobacco smoke, it is controversial whether smoking is a risk factor for the development of skin cancer. Some studies showed that smokers usually spend most of the time indoors because they are less active than non-smokers. A positive aspect of this model of life is reduced sun exposure $[67,68]$.

\section{Squamous cell carcinoma}

Some studies have proven that smoking is a risk factor for developing squamous cell carcinoma (SCC). On the other hand, some researchers believe that there is no correlation between nicotine and SCC $[69,70]$. It has been documented that keratoacanthoma is connected to smoking [71]. A case-control study including 78 patients with keratoacanthoma and 199 controls was conducted. It showed that $69.2 \%$ of patients with keratoacanthoma are smokers compared with $21.6 \%$ of controls [71].

\section{Squamous cell carcinoma in the oral cavity and smoking}

Oral SCC is frequently detected among people who are habitual smokers. The localisation is in the oral cavity, pharynx and larynx. Five-year survival rate is lower than
$50 \%$ [72]. Tobacco is one of the selected factors which increases the risk of developing that disease [73]. Initially it develops as a small lesion which does not look alarming. After that it can transform into a white or red spot. Then the medical intervention is very desirable. Waiting might have negative consequences such as a higher rate of morbidity and mortality [74].

\section{Basal cell carcinoma}

It has been documented that aetiology of basal cell carcinoma (BCC) is complex. Excessive exposure to UV radiation is a well-known risk factor for $\mathrm{BCC}$ development [75]. On the other hand, results of studies regarding BCC and smoking cigarettes are conflicting. There is a prevalence of smokers among women with $\mathrm{BCC}[76,77]$. Moreover, a retrospective medical record review of 220 patients with Mohs surgery shows that smoking is connected with developing of BCC larger than $1.0 \mathrm{~cm}$ in diameter [78]. However some studies showed no association between smoking and developing of BCC $[79,80]$.

\section{Melanoma}

Smoking is not a risk factor for developing cutaneous malignant melanoma. There are some studies on the protective role of smoking cigarettes [81-84]. It may be connected with the immunosuppressive effect of nicotine which can protect melanocytes from ultraviolet-induced inflammation.

\section{Anogenital cancer}

Smoking is a risk factor for developing anogenital skin cancers [85]. Moreover, the number of cigarettes smoked is directly connected with the estimated risk. A group of 903 patients with anogenital cancers was investigated in a population-based study. The study has demonstrated that $40 \%$ of people with vaginal and cervical cancer and $60 \%$ of those with vulvar and anal cancers were smokers compared to $25 \%$ of controls ( $O R=1.3-14.6)$ [86].

\section{Tobacco alternatives}

Study results indicate that effectiveness of different forms of nicotine addiction is low. The tobacco industry started to display special, very graphic pictures and warnings on the packs of cigarettes to show the negative consequences of smoking [87]. But the number of smokers still remains high. Consequently, heavy smoking patient management should also include tobacco harm reduction strategy. Alternatives like electronic cigarettes (e-cigarettes) and tobacco heating devices (heat-notburn products - $\mathrm{HnB}$ ) induce the perception of smoking, but without tobacco burning. Eliminating the tobacco burning process substantially reduced the number and levels of toxins in aerosol in comparison with combustible cigarette smoke. E-cigarettes consist of an atomizer, 
battery and special liquids (cartridge) - full of vegetable glycerine (VG) and/or propylene glycol (PG), nicotine, and flavours. There is a lack of standardization among a few thousand models of these products; the benefits and the health risks of e-cigarettes are debatable $[88,89]$. More importantly, some of them can come to the market from unknown sources. On the other hand, a raising number of studies show that heat-not-burn devices offer smokers a substantial reduction of harmful and potentially harmful chemical compounds in comparison to smoking continuation [90, 91]. In 2019, the first heat-not-burn device was authorised by the FDA in the US to be sold to smokers in the US market as an appropriate alternative for the protection of the public health. Some clinical experts recommend $\mathrm{HnB}$ devices as a harm reduction strategy after pharmacotherapy failure for heavy smokers [92].

\section{Conclusions}

No doubt that even short episodes of smoking negatively affect human health. A lot of chemical substances are produced during the process of smoking, which also pollutes our environment. People close to smokers also suffer from the effects of tobacco smoke. Smoking can cause the aggravation of many chronic diseases including dermatological ones. Moreover, usage of some medicines during smoking can decrease or increase their concentration in the blood leading to activity disorders. It is important for any doctor to promote awareness of the consequences of smoking. Despite the availability of many methods of counteracting tobacco addiction, their effectiveness is still insufficient. An alternative to smoking cigarettes after pharmacotherapy failure could be tobacco products based on heating tobacco ("heat-notburn'), the use of which may be associated with a lower cardiovascular risk.

\section{Conflict of interest}

The authors declare no conflict of interest.

\section{References}

1. Benowitz NL. Nicotine addiction. N Engl J Med 2010; 362: 2295-303.

2. Tanner JA, Chenoweth MJ, Tyndale RF. Pharmacogenetics of nicotine and associated smoking behaviors. Curr Top Behav Neurosci 2015; 23: 37-86.

3. Fowles J, Dybing E. Application of toxicological risk assessment principles to the chemical constituents of cigarette smoke. Tob Control 2003; 12: 424-30.

4. Bekki K, Uchiyama S, Ohta K, et al. Carbonyl compounds generated from electronic cigarettes. Int J Environ Res Public Health 2014; 11: 11192-200.

5. Mucha L, Stephenson J, Morandi N, Dirani R. Meta-analysis of disease risk associated with smoking, by gender and intensity of smoking. Gend Med 2006; 3: 279-91.
6. Izzotti A, Cartiglia C, Longobardi M, et al. Alterations of gene expression in skin and lung of mice exposed to lightand cigarette smoke. FASEB J 2004; 18: 1559-61.

7. Armstrong AW, Armstrong EJ, Fuller EN, et al. Smoking and pathogenesis of psoriasis: a review of oxidative, inflammatory and genetic mechanisms. Br J Dermatol 2011; 165: 1162-8.

8. Lonnberg AS, Skov L, Skytthe A, et al. Smoking and risk for psoriasis: a population-based twin study. Int I Dermatol 2016; 55: e72-8.

9. Hartmann-Boyce J, Chepkin SC, Weiyu Y, et al. Nicotine replacement therapy versus control for smoking cessation. Cochrane Database Syst Rev 2018; 5: CD000146.

10. Ortiz A, Grando SA. Smoking and the skin. Int I Dermatol 2012; 51: 250-62.

11. Just M, Ribera M, Monso E, et al. Effect of smoking on skin elastic fibres: morphometric and immunohistochemical analysis. Br J Dermatol 2007; 156: 85-91.

12. Yin L, Morita A, Tsuji T. Alterations of extracellular matrix induced by tobacco smoke extract. Arch Dermatol Res 2000; 292: 188-94.

13. Morita A. Tobacco smoke causes premature skin aging. J Dermatol Sci 2007; 48: 169-75.

14. Tanaka H, Ono Y, Nakata S, et al. Tobacco smoke extract induces premature skin aging in mouse. J Dermatol Sci 2007; 46: 69-71.

15. Doshi DN, Hanneman KK, Cooper KD. Smoking and skin aging in identical twins. Arch Dermatol 2007; 143: 1543-6.

16. Chung JH, Lee SH, Youn CS, et al. Cutaneous photodamage in Koreans: influence of sex, sun exposure, smoking, and skin color. Arch Dermatol 2001; 137: 1043-51.

17. Raduan AP, Luiz RR, Manela-Azulay M. Association between smoking and cutaneous ageing in a Brazilian population. J Eur Acad Dermatol Venereol 2008; 22: 1312-8.

18. Wong LS, Green HM, Feugate JE, et al. Effects of "secondhand" smoke on structure and function of fibroblasts, cells that are critical for tissue repair and remodeling. BMC Cell Biol 2004; 5: 13 .

19. Arredondo J, Hall LL, Ndoye A, et al. Central role of fibroblast alpha3 nicotinic acetylcholine receptor in mediating cutaneous effects of nicotine. Lab Invest 2003; 83: 207-25.

20. Snyder HB, Caughman G, Lewis J, et al. Nicotine modulation of in vitro human gingival fibroblast beta1 integrin expression. J Periodontol 2002; 73: 505-10.

21. Sorensen LT, Karlsmark T, Gottrup F. Abstinence from smoking reduces incisional wound infection: a randomized controlled trial. Ann Surg 2003; 238: 1-5.

22. Myles PS, lacono GA, Hunt JO, et al. Risk of respiratory complications and wound infection in patients undergoing ambulatory surgery: smokers versus nonsmokers. Anesthesiology 2002; 97: 842-7.

23. Sorensen LT, Horby J, Friis E, et al. Smoking as a risk factor for wound healing and infection in breast cancer surgery. Eur J Surg Oncol 2002; 28: 815-20.

24. Manassa EH, Hertl CH, Olbrisch RR. Wound healing problems in smokers and nonsmokers after 132 abdominoplasties. Plast Reconstr Surg 2003; 111: 2082-7.

25. Abbas SM, Hill AG. Smoking is a major risk factor for wound dehiscence after midline abdominal incision; case-control study. ANZ I Surg 2009; 79: 247-50.

26. Little SC, Hughley BB, Park SS. Complications with forehead flaps in nasal reconstruction. Laryngoscope 2009; 119: 1093-9. 
27. Campos JH, Gomes HC, dos-Santos WL, et al. Effect of nicotine treatment and withdrawal on random-pattern skin flaps in rats. Exp Toxicol Pathol 2008; 60: 449-52.

28. Akoz T, Akan M, Yildirim S. If you continue to smoke, we may have a problem: smoking's effects on plastic surgery. Aesthetic Plast Surg 2002; 26: 477-82.

29. Mercuri SR, Naldi L. Potential role of ustekinumab in the treatment of chronic plaque psoriasis. Biologics 2010; 4: 119-29.

30. Li W, Han J, Choi HK, Qureshi AA. Smoking and risk of incident psoriasis among women and men in the United States: a combined analysis. Am J Epidemiol 2012; 175: 402-13.

31. Setty AR, Curhan G, Choi HK. Smoking and the risk of psoriasis in women: Nurses' Health Study II. Am J Med 2007; 120: 953-9.

32. Armstrong AW, Armstrong EJ, Fuller EN, et al. Smoking and pathogenesis of psoriasis: a review of oxidative, inflammatory and genetic mechanisms. Br J Dermatol 2011; 165: 1162-8.

33. Fernandez-Real JM, Broch M, Vendrell J, Ricart W. Smoking, fat mass and activation of the tumor necrosis factor-alpha pathway. Int J Obes Relat Metab Disord 2003; 27: 1552-6.

34. Ryan C, Kirby B. Psoriasis is a systemic disease with multiple cardiovascular and metabolic comorbidities. Dermatol Clin 2015; 33: 41-55.

35. Moretti E, Collodel G, Mazzi L, et al. Resistin, interleukin-6, tumor necrosis factor-alpha, and human semen parameters in the presence of leukocytospermia, smoking habit, and varicocele. Fertil Steril 2014; 102: 354-60.

36. Mitrovic M, Ilic T, Stokic E, et al. Influence of glucoregulation quality on C-reactive protein, interleukin-6 and tumor necrosis factor-alpha level in patients with diabetes type 1. Vojnosanit Pregl 2011; 68: 756-61.

37. Anzengruber F, Augustin M, Radtke MA, et al. Smoking does not alter the therapy response to systemic anti-psoriatic therapies: a two-country, multi-centre, prospective, noninterventional study. Acta Derm Venereol 2019; 99: 871-7.

38. Glick ZR, Saedi N, Ehrlich A. Allergic contact dermatitis from cigarettes. Dermatitis 2009; 20: 6-13.

39. Linneberg A, Nielsen NH, Menne T, et al. Smoking might be a risk factor for contact allergy. J Allergy Clin Immunol 2003; 111: 980-4

40. Goel N, Singh BP, Arora N, Kumar R. Effect of smoking on atopic predisposition and sensitisation to allergens. Indian J Chest Dis Allied Sci 2008; 50: 329-33.

41. Bo K, Thoresen M, Dalgard F. Smokers report more psoriasis, but not atopic dermatitis or hand eczema: results from a Norwegian population survey among adults. Dermatology 2008; 216: 40-5.

42. Revuz JE, Canoui-Poitrine F, Wolkenstein P, et al. Prevalence and factors associated with hidradenitis suppurativa: results from two case-control studies. J Am Acad Dermatol 2008; 59: 596-601.

43. Matusiak L, Bieniek A, Szepietowski JC. Hidradenitis suppurativa and associated factors: still unsolved problems. J Am Acad Dermatol 2009; 61: 362-5.

44. Mandal A, Watson J. Experience with different treatment modules in hidradenitis suppurativa: a study of 106 cases. Surgeon 2005; 3: 23-6.

45. Happle R, Konig A. A lesson to be learned from Karl Marx: smoking triggers hidradenitis suppurativa. Br J Dermatol 2008; 159: 255-6.

46. Sartorius K, Emtestam L, Jemec GB, et al. Objective scoring of hidradenitis suppurativa reflecting the role of tobacco smoking and obesity. Br J Dermatol 2009; 161: 831-9.
47. Hana A, Booken D, Henrich C, et al. Functional significance of non-neuronal acetylcholine in skin epithelia. Life Sci 2007; 80: 2214-20.

48. Sabat R, Jemec GBE, Matusiak Ł, Kimball AB, Prens E, Wolk K. Hidradenitis suppurativa. Nat Rev Dis Primers 2020; 6: 18.

49. Schafer T, Nienhaus A, Vieluf D, et al. Epidemiology of acne in the general population: the risk of smoking. Br J Dermatol 2001; 145: 100-4.

50. Chuh AA, Zawar V, Wong WC, et al. The association of smoking and acne in men in Hong Kong and in India: a retrospective case-control study in primary care settings. Clin Exp Dermatol 2004; 29: 597-9.

51. Rombouts S, Nijsten T, Lambert J. Cigarette smoking and acne in adolescents: results from a cross-sectional study. J Eur Acad Dermatol Venereol 2007; 21: 326-33.

52. Su LH, Chen TH. Association of androgenetic alopecia with smoking and its prevalence among Asian men: a community-based survey. Arch Dermatol 2007; 143: 1401-6.

53. Trueb RM. Molecular mechanisms of androgenetic alopecia. Exp Gerontol 2002; 37: 981-90.

54. Trüeb RM. Association between smoking and hair loss: another opportunity for health education against smoking? Dermatology 2003; 206: 189-91.

55. Ghaussy NO, Sibbitt WL Jr, Qualls CR. Cigarette smoking, alcohol consumption, and the risk of systemic lupus erythematosus: a case-control study. J Rheumatol 2001; 28: 2449-53.

56. Chua MHY, Ng IAT, Cheung MWL, Mak A. Association between cigarette smoking and systemic lupus erythematosus: an updated multivariate bayesian metaanalysis. J Rheumatol 2020; 47: 1514-21.

57. Petri M, Thompson E, Abusuwwa R, et al. BALES: The Baltimore Lupus Environmental Study [abstract]. Arthritis Rheumatism 2001; 44: S331.

58. Bengtsson AA, Rylander L, Hagmar L, et al. Risk factors for developing systemic lupus erythematosus: a case-control study in southern Sweden. Rheumatology 2002; 41: 563-71.

59. Koskenmies S, Jarvinen TM, Onkamo $P$, et al. Clinical and laboratory characteristics of Finnish lupus erythematosus patients with cutaneous manifestations. Lupus 2008; 17: 337-47.

60. Miot HA, Bartoli Miot LD, Haddad GR. Association between discoid lupus erythematosus and cigarette smoking. Dermatology 2005; 211: 118-22.

61. Boeckler P, Milea M, Meyer A, et al. The combination of complement deficiency and cigarette smoking as risk factor for cutaneous lupus erythematosus in men: a focus on combined C2/C4 deficiency. Br J Dermatol 2005; 152: 265-70.

62. Jewell ML, McCauliffe DP. Patients with cutaneous lupus erythematosus who smoke are less responsive to antimalarial treatment. J Am Acad Dermatol 2000; 42: 983-7.

63. Kreuter A, Gaifullina R, Tigges C, et al. Lupus erythematosus tumidus: response to antimalarial treatment in 36 patients with emphasis on smoking. Arch Dermatol 2009; 145: 244-8.

64. Hugel R, Schwarz T, Glaser R. Resistance to hydroxychloroquine due to smoking in a patient with lupus erythematosus tumidus. Br J Dermatol 2007; 157: 1081-3.

65. Mentens G, Lambert J, Nijsten T. Polymorphic light eruption may be associated with cigarette smoking and alcohol consumption. Photodermatol Photoimmunol Photomed 2006; 22: 87-92.

66. Berman ML, Byron MJ, Hemmerich N, et al. Communicating tobacco product information to the public. Food Drug Law J 2017; 72: 386-405. 
67. Kimm SY, Glynn NW, Kriska AM, et al. Decline in physical activity in black girls and white girls during adolescence. N Engl J Med 2002; 347: 709-15.

68. Santmyire BR, Feldman SR, Fleischer Jr AB. Lifestyle highrisk behaviors and demographics may predict the level of participation in sun-protection behaviors and skin cancer primary prevention in the United States: results of the 1998 National Health Interview Survey. Cancer 2001; 92: 1315-24.

69. De Hertog SA, Wensveen CA, Bastiaens MT, et al. Relation between smoking and skin cancer. J Clin Oncol 2001; 19: 231-8.

70. Grant WB. Smoking overlooked as an important risk factor for squamous cell carcinoma. Arch Dermatol 2004; 140: 362-3.

71. Miot HA, Miot LD, da Costa AL, et al. Association between solitary keratoacanthoma and cigarette smoking: a casecontrol study. Dermatol Online J 2006; 12: 2.

72. Le Campion ACOV, Ribeiro CMB, Luiz RR, et al. Low survival rates of oral and oropharyngeal squamous cell carcinoma. Int J Dent 2017; 2017: 5815493.

73. Azad MD, Pervaiz G, Pervaiz MK. Most significant risk factors for head and neck cancer. J Stat 2007; 14: 1-12.

74. Neville BW, Day TA. Oral cancer and precancerous lesions. CA Cancer J Clin 2002; 52: 195-215.

75. Lesiak A, Czuwara J, Kamińska-Winciorek G, et al. Basal cell carcinoma. Diagnostic and therapeutic recommendations of Polish Dermatological Society. Dermatol Rev 2019; 106: 107-26.

76. Milan T, Verkasalo PK, Kaprio J, et al. Lifestyle differences in twin pairs discordant for basal cell carcinoma of the skin. Br J Dermatol 2003; 149: 115-23.

77. Boyd AS, Shyr Y, King Jr LE. Basal cell carcinoma in young women: an evaluation of the association of tanning bed use and smoking. J Am Acad Dermatol 2002; 46: 706-9.

78. Smith JB, Randle HW. Giant basal cell carcinoma and cigarette smoking. Cutis 2001; 67: 73-6.

79. De Hertog SA, Wensveen CA, Bastiaens MT, et al. Relation between smoking and skin cancer. J Clin Oncol 2001; 19: 231-8.

80. Corona R, Dogliotti E, D’Errico M, et al. Risk factors for basal cell carcinoma in a Mediterranean population: role of recreational sun exposure early in life. Arch Dermatol 2001; 137 1162-8.

81. Grant WB. A meta-analysis of second cancers after a diagnosis of nonmelanoma skin cancer: additional evidence that solar ultraviolet-B irradiance reduces the risk of internal cancers. J Steroid Biochem Mol Biol 2007; 103: 668-74.

82. Freedman DM, Sigurdson A, Doody MM, et al. Risk of melanoma in relation to smoking, alcohol intake, and other factors in a large occupational cohort. Cancer Causes Control 2003; 14: 847-57.

83. Sondermeijer L, Lamboo LGE, de Waal AC, et al. Cigarette smoking and the risk of cutaneous melanoma: a case-control study. Dermatology 2020; 236: 228-36.

84. Odenbro A, Gillgren P, Bellocco R, et al. The risk for cutaneous malignant melanoma, melanoma in situ and intraocular malignant melanoma in relation to tobacco use and body mass index. Br J Dermatol 2007; 156: 99-105.

85. Kutlubay Z, Engin B, Zara T, Tüzün Y. Anogenital malignancies and premalignancies: facts and controversies. Clin Dermatol 2013; 31: 362-73.

86. Metelitsa Al, Lauzon GJ. Tobacco and the skin. Clin Dermatol 2010; 28: 384-90.

87. Benowitz NL, Hall SM, Stewart S, et al. 3rd Nicotine and carcinogen exposure with smoking of progressively reduced nicotine content cigarette. Cancer Epidemiol Biomarkers Prev 2007; 16: 2479-85.
88. Benowitz NL. Smokeless tobacco as a nicotine delivery device: harm or harm reduction? Clin Pharmacol Ther 2011; 90 : 491-3.

89. Farsalinos KE, Le Houezec J. Regulation in the face of uncertainty: the evidence on electronic nicotine delivery systems (e-cigarettes) Risk Manag Healthc Policy 2015; 8: 157-67.

90. Marszałek D, Niewada M, Mela A, et al. Comparison of tobacco heating products and conventional cigarette: a systematic review. J Health Policy 2019; 2. DOI:10.7365/JHPOR. 2019.2.3.

91. Simonavicius E, McNeill A, Shahab L, Brose LS. Heat-notburn tobacco products: a systematic literature review. Tob Control 2019; 28: 582-94.

92. Szymański FM, Kuna P, Płatek AE, et al. Heat-not-burn tobacco products and patient health: Expert Group opinion. Choroby Serca i Naczyń 2019; 16: 135-42. 